\section{Complete Denture Biofilm after Brushing with Specific Denture Paste, Neutral Soap and Artificial Saliva}

Helena de Freitas Oliveira Paranhos ${ }^{1}$, Antônio Eduardo Sparça Salles ${ }^{1}$, Leandro Dorigan de Macedo ${ }^{1}$, Cláudia Helena da Silva-Lovato ${ }^{1}$, Valéria Oliveira Pagnano ${ }^{1}$, Evandro Watanabe ${ }^{2}$
'Department of Dental Materials and Prosthodontics; ${ }^{2}$ Department of Restorative Dentistry, Ribeirão Preto Dental School, USP - University of São Paulo, Ribeirão Preto, SP, Brazil

Correspondence: Profa. Dra. Helena de Freitas Oliveira Paranhos, Avenida do Café, S/N, 14040-904 Ribeirão Preto, SP, Brasil. Tel: +55-16-36024031. e-mail: helenpar@forp.usp.br

\begin{abstract}
This study compared the levels of biofilm in maxillary and mandibular complete dentures and evaluated the number of colony-forming units (cfu) of yeasts, after using auxiliary brushing agents and artificial saliva. Twenty-three denture wearers with hyposalivation and xerostomia were instructed to brush the dentures 3 times a day during 3 weeks with the following products: Corega Brite denture dentifrice, neutral liquid soap, Corega Brite combined with Oral Balance (artificial saliva) or tap water. For biofilm quantification, the internal surfaces of the dentures were disclosed, photographed and measured using a software. For microbiological analysis, the biofilm was scrapped off, and the harvested material was diluted, sown in CHROMagar ${ }^{\mathrm{TM}}$ Candida and incubated at $37^{\circ} \mathrm{C}$ for $48 \mathrm{~h}$. Data were analyzed statistically by two-way ANOVA and Tukey's test $(\alpha=0.05)$. Mandibular dentures presented a mean biofilm percentage $(\mu=26.90 \pm 21.10)$ significantly greater than the maxillary ones $(\mu=18.0 \pm 15.0)(p<0.05)$. Brushing using Corega Brite combined with Oral Balance $(\mu=15.87 \pm 18.47)$ was more effective $(p<0.05)$ than using the denture dentifrice $(\mu=19.47 \pm 17.24)$, neutral soap $(\mu=23.90 \pm 18.63)$ or tap water (control; $\mu=32.50 \pm 20.68$ ). For the microbiological analysis, the chi-square test did not indicate significant difference between the hygiene products for either type of denture. The more frequently isolated species of yeasts were $C$. albicans, $C$. tropicalis and C. glabrata. In conclusion, mandibular dentures had more biofilm formation than maxillary ones. Denture brushing with Corega Brite dentifrice combined with the use of Oral Balance was the most effective method for reduction of biofilm levels, but the use of products did not show difference in yeast cfu counts.
\end{abstract}

Key Words: complete denture, biofilm, denture cleansers, brushing, yeasts.

\section{Introduction}

Complete denture biofilm can be removed by mechanical (brushing and ultrasonic device) and chemical methods (alkaline peroxide and hypochlorite, acids, enzymes and disinfectants). Among these, brushing with conventional and specific dentifrices is the most common method applied for routine denture biofilm control (1) and has been proven effective $(2,3)$. Soap, as an auxiliary hygiene agent, is an accessible abrasive-free product and has been claimed as effective against anaerobic microorganisms and yeasts (4) and stains (5). Studies have indicated that the combination of coconut soap with hypochlorite is an effective cleansing method (6). However, randomized clinical trials regarding its effectiveness as an isolated cleansing method have not been reported (7).

A factor that can adversely affect oral health is xerostomia (dry mouth sensation), which generally is followed by hyposalivation. The reduction of salivary flow affects the lubrication of oral tissues, diminishing the cleaning of residues and the amount of natural antimicrobial salivary agents, favoring the appearance of infections (8).
Aiming at restoring the natural antimicrobial capacity of the saliva in xerostomic individuals, an enzymatic system has been investigated, containing lactoferrin, lysozyme and lactoperoxidase with capacity to increase the levels of agents such as tiocianate (SCN-) and hydrogen peroxide $\left(\mathrm{H}_{2} \mathrm{O}_{2}\right)$, thus inhibiting the growth of Candida albicans and other microorganisms (9). Reduction of the supragingival biofilm has been observed with the use of this system (10), but there is no available research evaluating the effect of these products on denture surfaces $(7,11)$.

The hypothesis that denture biofilm accumulation can be greater in individuals with xerostomia prompts a need for the evaluation of cleansers and artificial saliva capable of inhibiting biofilm formation with an effective antimicrobial action against yeasts like fungi, which are important etiologic agents of diseases in complete denture wearers.

The objective of this study was to compare the levels of biofilm on the surfaces of maxillary and mandibular complete dentures after the use of two auxiliary brushing agents (specific denture dentifrice and neutral liquid soap) 
and artificial saliva (Oral Balance ${ }^{\circledast}$ ), as well as to evaluate quantitatively and qualitatively the presence of yeasts on the denture surfaces after the use of each tested cleaning product.

\section{Material and Methods}

Twenty-three edentulous patients ( 14 females and 9 males) aged 44 to 84 years (mean age $=65$ years), wearers of maxillary and mandibular complete dentures, were recruited from the Complete Denture Clinic of Ribeirão Preto Dental School, University of São Paulo, Brazil. All subjects were required to have good general health but present xerostomia and hyposalivation. The dentures had been worn for about 1 to 5 years and had biofilm scores $\geq 1$ according to the Additive Index (3). Xerostomia and hyposalivation had been diagnosed based on a questionnaire and sialometry test (8), respectively, at the same clinical facility. Hyposalivation was considered when the saliva flow rate was less than $1 \mathrm{~mL} / \mathrm{min}$.

Approval for the study was obtained from institutional Ethics Committee (\#2003.1.355.58.0) and informed consent was given by all patients.

Initially, the internal surfaces were disclosed with 1\% neutral red, cleansed using a denture brush (Medic Denture Brush-Condor S.A., São Bento do Sul, SC, Brazil) with neutral liquid soap (JOB-Química Ltda, São Paulo, SP, Brazil) for total biofilm elimination. Subsequently, each volunteer received a toothbrush (Oral B Indicator 40 soft; Gillette do Brasil Ltda., Manaus, AM, Brazil) and was instructed to brush the dentures after each meal for 2 min with the following auxiliary agents: tap water (control $-\mathrm{W}$ ); Corega Brite dentifrice for complete dentures (CB; Stafford-Miller Indústria Ltda, Rio de Janeiro, RJ, Brazil); Neutral liquid soap - pH 12 (neutral) (12) (S; Selvática Farmácia Homeopática e de Manipulação, Ribeirão Preto, SP, Brazil) and CB + Oral Balance artificial saliva (OB; Laclede do Brasil Ltda., São Paulo, SP, Brazil). The volunteers were also instructed to rinse the mouth with tap water after brushing and keep the dentures immersed in tap water overnight.

This study was set up using a crossover design. Each volunteer was randomly assigned to wear one of the products for 3 weeks. After this period, the volunteer returned to exchange the product for another. Between products, the volunteer used running tap water (control) for 7 days. Every week, the denture internal surfaces were disclosed with 1\% neutral red solution and digital photographs were obtained (Canon EOS Rebel; Canon Inc., Tokyo, Japan) at $45^{\circ}$. The areas (total and disclosed) were measured with Image Tool software, version 3.0 (UTHSCSA, San Antonio, TX, USA) (13). Biofilm percentage was calculated by the relation between the biofilm disclosed area multiplied by 100 and the total analyzed surface.
The researcher eliminated the biofilm after taking the photographs as described above.

For the microbiological analysis, at the end of the third week, the biofilm was scrapped off by brushing with saline and collected (14). The dilutions in solution drain plug PBS $\left(10^{-4}\right)$ were sown in the CHROMagar ${ }^{\mathrm{TM}}$ Candida culture medium (CM) under laminar flow, in duplicate and incubated at $37^{\circ} \mathrm{C}$ for $48 \mathrm{~h}$. The number of colony-forming units (cfu) of yeast-like fungi was counted and identification was made based on the macroscopic morphology and use of a color code (C. albicans - green; C. dubliniensis - green; C. glabrata - purpura; C. tropicalis - blue; C. parapsilosis - white). The identity of the isolated yeasts was obtained by the tests of tube formation of germination (GT), chlamydoconidia and tests of fermentation and assimilation.

Data obtained from the efficacy of the denture cleaning products were examined using a two-way ANOVA and Tukey's test. The reduction of cfu counts was analyzed by the chi-square test. The significance level was set at 5\% for all analyses.

\section{Results}

The mandibular dentures presented a mean biofilm percentage $(\mu=26.90 \pm 21.10)$ significantly greater than the maxillary ones $(\mu=18.0 \pm 15.0)(p<0.05)$. Brushing using Corega Brite combined with Oral Balance ( $\mu=15.87 \pm$ 18.47) was more effective $(p<0.05)$ than using the denture dentifrice $(\mu=19.47 \pm 17.24)$, neutral soap $(\mu=23.90 \pm$ 18.63) or tap water (control; $\mu=32.50 \pm 20.68$ ) (Table 1).

The mean percentages of biofilm for each product are graphically illustrated in Figures 1 and 2.

The cfu counts for yeast species were transformed in $\log _{10}$ (Figs. 3 and 4). Table 2 shows that yeast incidence in the maxillary complete dentures was greater than in the mandibular dentures. High counts of $C$. albicans were found in both dentures.

The total frequency values for the maxillary and mandibular dentures (Table 2) were obtained and the chisquared test did not indicate any statistically significant difference among the brushing products ( $\mathrm{PHo}=76.75 \%$; $\left.x^{2}=1.14\right)$.

Table 1. Mean percentage of biofilm on the internal surface of the complete dentures after use of the products

\begin{tabular}{lc}
\hline Product & Means and S.D. \\
\hline Tap water (control) & $32.50 \pm 20.68^{\mathrm{a}}$ \\
Liquid neutral soap & $23.90 \pm 18.63^{\mathrm{ab}}$ \\
Corega Brite denture dentifrice & $19.47 \pm 17.24^{\mathrm{bc}}$ \\
Corega Brite + Oral Balance (artificial saliva) & $15.87 \pm 18.47^{\mathrm{c}}$ \\
\hline
\end{tabular}

Same letters indicate statistically similar means (Tukey's value $=0.46$ ). 


\section{Discussion}

The lactoperoxidase enzyme system found in artificial saliva is indicated to replace or improve the antimicrobial capacity (9), presenting antibacterial activity in vitro and clinical efficacy when incorporated in dentifrices (3). The artificial saliva used in this study does not present any systemic or local side effects, alleviates xerostomia symptoms (15) and does not cause discoloration or pigmentation of the acrylic resin (16).

In this study, using an auxiliary agent was proven necessary, as it promoted greater biofilm reduction than seen in the control group (Table 1). In the search for an alternative material, soap was chosen due to the absence of abrasiveness (17), easy access and low cost for patients. No medicaments or antiseptic agents were added to its composition, enabling to evaluate its cleaning capacity (12). The neutral pH aimed at diminishing the possibilities of allergic reactions or unpleasant taste, and the liquid form to facilitate application to the brush $(3,12)$. Sodium sulfate lauryl was associated as a prevailing agent, as well as sulfate lauryl triethylamine and betaine cocamidopropyl, also found in the formulation of the toothpaste Corega Brite. According to Landa et al. (18), the association of tensoactive products facilitates penetration of the product into the biofilm. The incorporation of sulfate lauryl in hygienic cleansers by immersion (Kleenite and Mersene) resulted in greater efficacy, acting as a soluble agent of proteins (4).

In the present study, brushing with Corega Brite was more effective than brushing with soap, a fact explained by the presence of solid components, such as titanium dioxide, silicon and silica dioxide in the dentifrice, which increases the mechanical clinical ability $(3,19)$. Efficacy of the detergents depends mainly on their penetration into

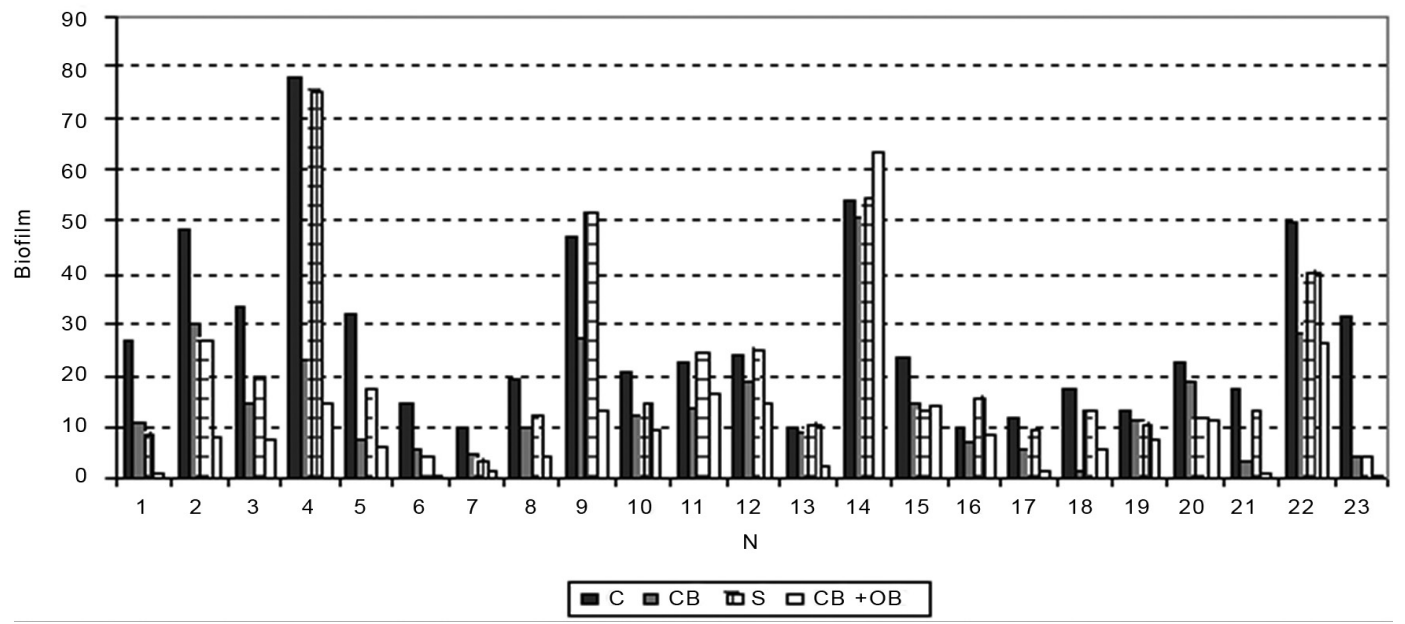

Figure 1. Average percentage of biofilm in the internal surface of the maxillary complete denture after the use of tap water (control - C), Corega Brite (CB), Neutral Soap (S) and Corega Brite associated with daily use of artificial saliva (CB + OB).

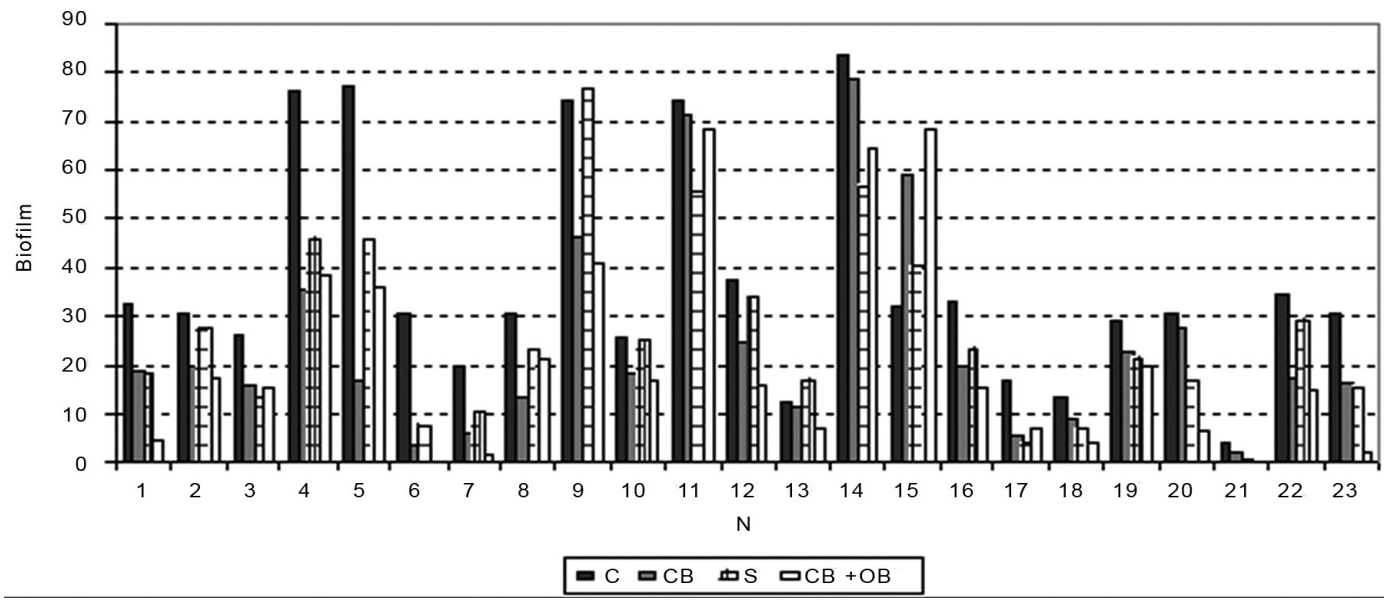

Figure 2. Average percentage of biofilm in the internal surface of the lower complete denture after use of tap water (control - C), Corega Brite (CB), Neutral Soap (S) and Corega Brite associated with daily use of artificial saliva (CB + OB). 
the biofilms (18) and the maturation biofilm is a barrier that makes this process slow and partial most of the time. According to Goddson (20), the components of dentifrices and mouthrinses take 2 min on average for satisfactory

Table 2. Frequency of colony-forming units (cfu) in maxillary and mandibular complete dentures after use of the products

\begin{tabular}{|c|c|c|c|c|c|c|c|c|c|c|}
\hline \multirow{2}{*}{ Yeast } & \multicolumn{5}{|c|}{ Maxillary } & \multicolumn{5}{|c|}{ Mandibular } \\
\hline & W & CB & $\mathrm{S}$ & $\mathrm{CB}+\mathrm{OB}$ & Total & W & $\mathrm{CB}$ & $S$ & $\mathrm{CB}+\mathrm{OB}$ & Total \\
\hline C. albicans & 12 & 11 & 15 & 9 & 47 & 6 & 6 & 9 & 7 & 28 \\
\hline C. glabrata & 7 & 8 & 7 & 9 & 31 & 5 & 5 & 4 & 6 & 20 \\
\hline C. tropicalis & 7 & 4 & 7 & 6 & 24 & 6 & 3 & 7 & 6 & 22 \\
\hline C. dubliniensis & 6 & 5 & 4 & 2 & 17 & 2 & 4 & 2 & 2 & 10 \\
\hline C. parapsilosis & 2 & 5 & 1 & 1 & 9 & 3 & 2 & 0 & 3 & 8 \\
\hline Total & 34 & 33 & 34 & 27 & 128 & 22 & 20 & 22 & 24 & 88 \\
\hline
\end{tabular}

absorption. Considering the average brushing time and the product absorption into the biofilm, it can be deduced that time was a determinant factor for the efficacy of soap, thus interfering in its cleaning capacity. Longer exposure time to the product before brushing, in addition to incorporating antiseptic agents or tensoactive products with greater penetration capacity, should be assessed. These results disagree from the study where there was no difference between Colgate Antitartar dentifrice and soap (5). This disagreement can be explained by the differences in methodologies, as McCabe et al. (5) employed brushing performed by the professional and score attribution methodology for biofilm quantification. In the

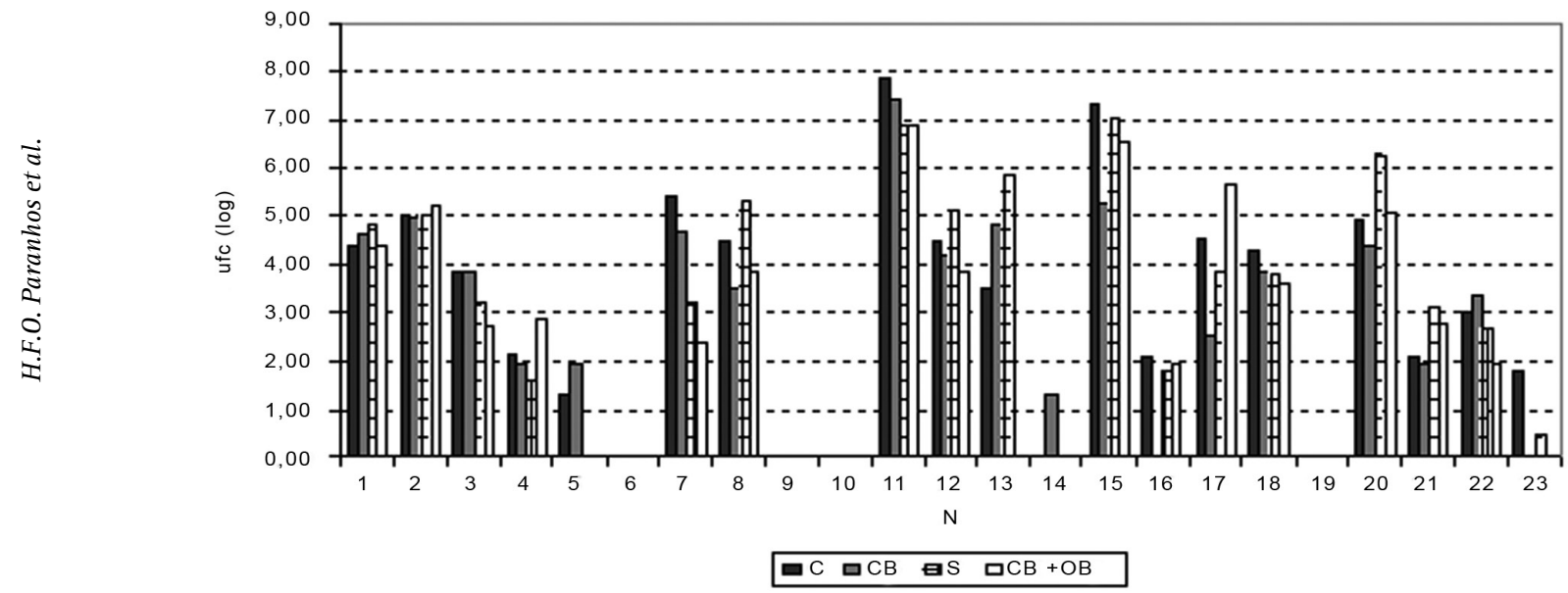

Figure 3. Total of ufcs ( $\log 10)$ of the yeast found in the internal surface of upper complete denture after use of tap water (control - C), Corega Brite (CB), Neutral Soap (S) and Corega Brite associated with daily use of artificial saliva (CB + OB).

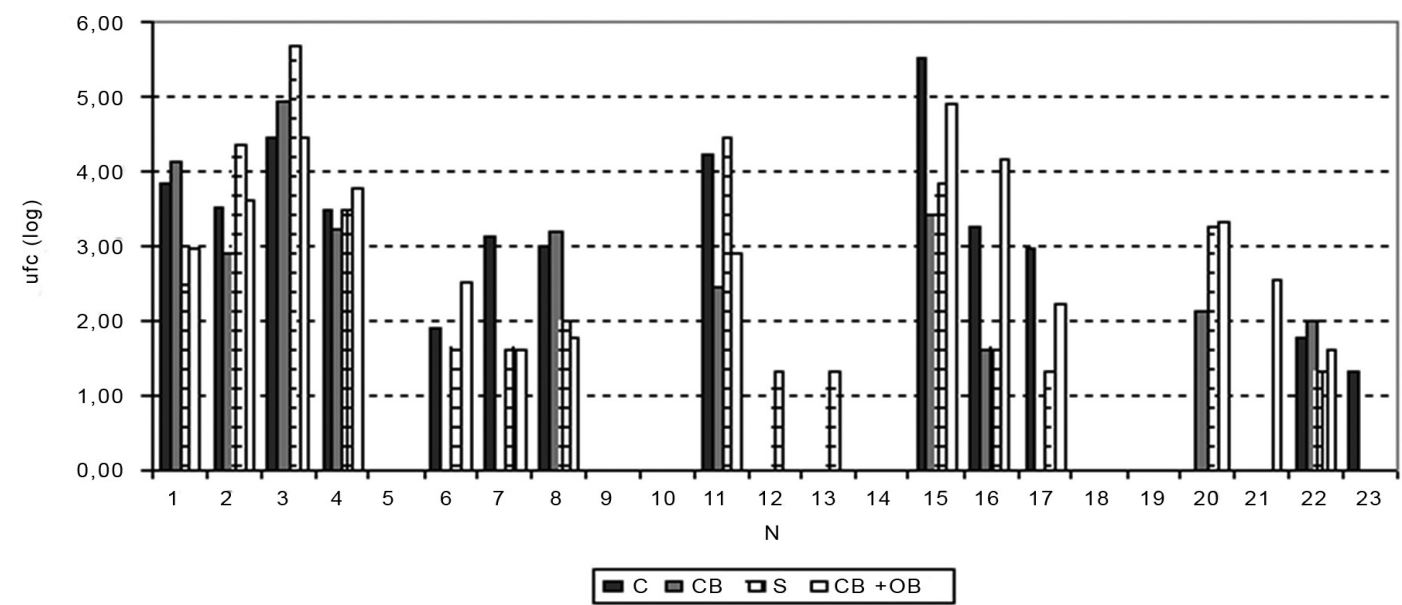

Figure 4. Total of ufcs $(\log 10)$ of the yeast found in the internal surface of lower complete denture after use of tap water (control - C), Corega Brite (CB), Neutral Soap (S) and Corega Brite associated with daily use of artificial saliva (CB + OB). 
present study, brushing was performed by the volunteers and photography combined with quantitative analysis was employed to obtain an objective evaluation of the biofilm levels (13). The mandibular dentures present a mean biofilm percentage significantly greater than the maxillary ones. This fact could be explained by the retaining capacity of the maxillary dentures as well as its shape. The mandibular dentures form a considerable reservoir of microorganisms, emphasizing the need for good oral hygiene.

Despite observing similarity in the effectiveness of the auxiliary agents employed in this study in terms of reduction of yeasts, it is unknown whether higher alkalinity of soap could generate the same results. Gibbson et al. (21) verified in vitro that the acid and alkaline detergents were more efficacious than the neutral detergent in the removal of some types of bacteria (Staphylococcus aureus and Pseudomonas aeruginosa) initially adhered to the metallic specimens. However, Barnabé et al. (6), using the same microbiological harvesting technique, found that cleaning with coconut soap produced no significant reduction of Streptococcus mutans and C. albicans on the biofilm of complete dentures.

Regarding Corega Brite denture dentifrice, its denture biofilm removal capacity has been demonstrated, but its antimicrobial activity has not been evaluated. Panzeri et al. (3) found that two experimental dentifrices containing $1 \%$ chloramine $T$ and $0.01 \%$ fluorosurfactant were able to reduce biofilm coverage and mutans streptococci counts after the clinical trial stage; however, yeasts from Candida genus on denture bases were not affected by the tested dentifrices. Perhaps a significant reduction for Candida sp. counts would only be expected with dentifrices with high concentrations of active substances like cetylpyridinium chloride (19).

The antimicrobial system in the artificial saliva presented clinical efficacy in biofilm removal (Table 1). Studies give emphasis to its antimicrobial effect (bactericidal or bacteriostatic) on planktonic cells, which are more susceptible to the lactoperoxidase system, reducing the cfu counts on the surface of the dentures (22). In vitro tests show efficacy of the lactoperoxidase system against fungi (9). However, the microbiological analysis (Table 2) did not evidence any significant effectiveness of this system, agreeing with the previous findings where the use of artificial saliva against the microbiota in geriatric patients with xerostomia produced no significant reduction of yeasts (23). In addition to the barrier promoted by the biofilm mass against the antimicrobials, the efficacy observed in vitro is relative, since the cultivated microorganisms may offer less resistance to certain agents (22). The results showed that mechanical biofilm removal alone was not sufficient to promote reduction of yeasts, strains that normally colonize acrylic resin surface. These observations corroborate with the findings of Barnabé et al. (6), reinforcing the need to use of chemical agents to reduce the number of viable microorganisms. The literature has emphasized the ability of decontamination promoted by various chemical agents $(4,24)$ and favors the use of this hygiene, especially in patients with impaired manual dexterity (11). Future studies should assess the effectiveness of these auxiliary agents associated to chemical methods, by a randomized clinical trial design.

Similar to other studies $(19,24)$, C. albicans was the most frequently isolated species in the present study (Table 2), followed by C. glabrata and C. tropicalis. The highest frequency of $C$. albicans and $C$. glabrata found in this study agree with the findings of Grimoud et al. (23), who observed similar prevalence of these species in the saliva of patients with reduced salivary flow. The $C$. dubliniensis is a recently described Candida species combined with oral candidosis and frequently found in immunocompromised patients; it exhibits a high similarity to $C$. albicans. The use of the CHROMagar ${ }^{\mathrm{TM}}$ medium is advantageous to facilitate the detection of mixtures of yeast species from different samples on a single isolation plate. This medium is particularly useful as $C$. dubliniensis is often co-isolated with C. albicans (25).

From the obtained data, it may be concluded that the mandibular dentures presented a significantly greater mean biofilm percentage than the maxillary dentures. Brushing with a specific denture cleansing paste results in better denture cleansing than brushing with neutral liquid soap or tap water alone. The artificial saliva showed a adjuvant and preventive efficacy to reduce biofilm levels from complete dentures. None of the trial methods resulted in a significant reduction of yeast cfu counts. The most frequently isolated yeast species were $C$. albicans, $C$. tropicalis and $C$. glabrata.

\section{Resumo}

Este estudo comparou os niveis de biofilme em próteses totais maxilares e mandibulares, e analisou o número de unidades formadoras de colônias de leveduras, após o uso de agentes auxiliares da escovação e saliva artificial. Vinte e três usuários de próteses totais com hipossalivação e xerostomia foram orientados a escovar as dentaduras 3 vezes ao dia durante 3 semanas com os seguintes produtos: Corega Brite (dentifrício para prótese), sabonete líquido neutro, Corega Brite associado com o uso do Oral Balance (saliva artificial) ou água de torneira. Para a quantificação do biofilme, as superficies internas das próteses totais foram evidenciadas, fotografadas e o biofilme quantificado com o auxilio de um software. Para a análise microbiológica, o biofilme foi removido por escovação, coletado, diluido, semeado em meio seletivo $\mathrm{CHROMagar}^{\mathrm{TM}}$ Candida e incubado a $37^{\circ} \mathrm{C}$ por $48 \mathrm{~h}$. A análise de variância para dois fatores $(\mathrm{p}<0,05 \%)$ mostrou que as próteses mandibulares apresentaram uma média de porcentagem de biofilme $(\mu=26,90 \pm 21,10)$ maior que as maxilares $(\mu=18 \pm 15)$. 0 teste complementar de Tukey $(0,46 ; p<5 \%)$ mostrou que a escovação com Corega Brite e Oral Balance $(\mu=15,87 \pm 18,47)$ foi mais efetiva que 0 dentifricio $(\mu=19,47 \pm 17,24)$, sabonete neutro $(\mu=23,90 \pm 18,63)$, ou água de torneira (controle; $\mu=32,50 \pm 20,68$ ). Em relação à análise 
microbiológica, o teste de Qui-Quadrado não indicou diferença entre os produtos de higiene, para ambas as próteses. As espécies de leveduras mais comumente isoladas foram $C$. albicans, $C$. tropicalis e $C$. glabrata. Em conclusão, as próteses mandibulares apresentaram mais biofilme do que as maxilares. Além disso, a escovação das próteses com o Corega Brite associado ao uso do Oralbalance foi o método mais efetivo na redução dos niveis de biofilme, entretanto o uso dos produtos não demonstrou diferença no número de ufc de leveduras.

\section{Acknowledgements}

The authors would like to thank Laclede do Brasil Ltda. for the artificial saliva Oralbalance. The authors express their gratitude and consideration to Professor Izabel Yoko Ito (in memoriam) from the Department of Clinical, Toxicological and Bromatological Analyses of the School of Pharmaceutical Sciences of Ribeirão Preto, USP - University of São Paulo, Brazil, for her important contribution to this study.

\section{References}

1. Peracini $A$, Andrade IM, Paranhos HFO, Silva CHL, Souza RF. Behaviors and habits of hygiene for complete denture wearers. Braz Dent J 2010;21:247-252.

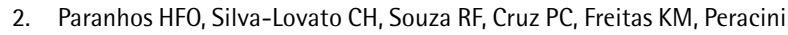
A. Effects of mechanical and chemical methods on denture biofilm accumulation. J Oral Rehabil 2007;34:606-612.

3. Panzeri H, Lara EHG, Paranhos HFO, Silva-Lovato CH, Souza RF, SouzaGulgelmin MCM, et al.. In vitro and clinical evaluation of specific dentifrices for complete denture hygiene. Gerodontol 2009;26:26-33.

4. Moore TC, Smith DE, Kenny GE. Sanitization of dentures by several denture hygiene methods. J Prosthet Dent 1984;52:158-163.

5. McCabe JF, Murray ID, Kelly PJ. The efficacy of denture cleansers. Eur J Prosthodont Restor Dent 1995;3:203-207.

6. Barnabé W, Mendonça Neto T, Pimenta FC, Pegoraro LF, Scolaro JM. Efficacy of sodium hypochlorite and coconut soap used as disinfecting agents in the reduction of denture stomatitis, Streptococcus mutans and Candida albicans. J Oral Rehabil 2004;31:453-459.

7. Souza RF, Paranhos HFO, Silva-Lovato CH, Abu-Naba'a L, Fedorowicz Z, Gurgan CA. Interventions for cleaning dentures in adults. Cochrane Database Syst Rev 2009;4:CD007395.

8. Sreebny LM. Saliva in health and disease: an appraisal and update. Int Dent J 2000;50:140-161.

9. Tevonuo J. Clinical applications of antimicrobial host proteins lactoperoxidase, lyzozyme and lactoferrina in xerostomia: efficacy and safety. Oral Dis 2002;8:23-29.

10. Toljanic JA, Siddqui AA, Pettereson GL, Irwin ME. An evaluation of a dentifrice containing salivary peroxidase elements for the control of gingival diseases in patients with irradiated head and neck cancer. J Prosth Dent 1996;76:292-295.

11. Felton D, Cooper L, Duqum I, Minsley G, Guckes A, Haug S, et al..
Evidence-based guidelines for the care and maintenance of complete dentures: a publication of the American College of Prosthodontists. J Prosthodont 2011;20:S1-S12.

12. Salles AES, Macedo LD, Fernandes RAG, Silva-Lovato CH, Paranhos HFO. Comparative analysis of biofilm levels in complete upper and lower dentures after brushing combined with specific denture paste and neutral soap. Gerodontol 2007;24:217-223.

13. Silva-Lovato CH, Totti AMG, Paranhos HFO, Totti VG. Evaluation of a computerized method for denture biofilm quantification: interexaminer reproducibility. J Prosthodont 2009;18:332-336.

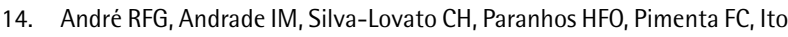
IY. Prevalence of mutans streptococci isolated from complete dentures and their susceptibility to mouthrinses. Braz Dent J 2011;22:62-67.

15. Matear DW, Barbaro J. Effectiveness of saliva substitute products in the treatment of dry mouth in the elderly: a pilot study. J R Soc Health 2005;125:35-41.

16. Samarawickrama DYD. Saliva substitutes: how effective and safe are they? Oral Dis 2002;8:177-179.

17. Sofou A, Emmanouil J, Peultzfeldt A, Owall B. The effect of different polishing techniques on the surface roughness of acrylic resin materials. Eur J Prosthodont Restor Dent 2001;9:117-122.

18. Landa AS, van der Mei HC, Busscher HJ. Detachment of linking film bacteria from enamel surfaces by oral rinses and penetration of sodium lauryl sulphate through an artificial oral biofilm. Adv Dent Res 1997;11:528-538.

19. Paranhos HFO, Lara EHG, Panzeri H, Candido RC, Ito IY. Capacity of denture plaque removal and antimicrobial action of a specific paste formulated for denture cleaning. Braz Dent J 2000;11:97-104.

20. Goodson JM. Pharmacokinetic principles controlling efficacy of oral therapy. J Dent Res 1989;68:1625-1632.

21. Gibbson H, Taylor JH, Hall KE, Holah JT. Effectiveness of cleaning techniques used in the food industry in terms of the removal of bacterial biofilms. J Appl Microbiol 1999;87:41-48.

22. van der Mei HC, White DJ, Atema-Smit J, van de Belt-Gritter E, Busscher HJ. A method to study sustained antimicrobial activity of rinse and dentifrice components on biofilm viability in vivo. J Clin Periodontol 2006;33:14-20.

23. Grimoud AM, Lodter JP, Marty N, Andrieu S, Bocquet $H$, Linas MD, et al.. Improved oral hygiene and Candida species colonization level in geriatric patients. Oral Dis 2005;11:163-169.

24. Webb BC, Thomas J, Whittle T. A 2-year of Candida-associated denture stomatitis treatment in aged care subjects. Gerodontol 2005;22:168176.

25. Campanha NH, Neppelenbroek KH, Spolidorio DMP, Spolidorio LC, Pavarina AC. Phenotypic methods and commercial systems for the discrimination between C. albicans and C. dubliniensis. Oral Dis 2005;11:392-398. 